https://helda.helsinki.fi

\title{
Toponyms in Manila and Cavite, Philippines
}

\section{Lesho, Marivic}

de Gruyter

2018

Lesho , M \& Sippola , E M 2018 , Toponyms in Manila and Cavite, Philippines . in T Stolz \& I

Warnke (eds), Vergleichende Kolonialtoponomastik : Strukturen und Funktionen kolonialer

Ortsbenennung . Koloniale und Postkoloniale Linguistik / Colonial and Postcolonial

Linguistics , no. 12 , de Gruyter , Berlin , pp. 317-332 . https://doi.org/10.1515/9783110608618-008

http://hdl.handle.net/10138/324228

https://doi.org/10.1515/9783110608618-008

unspecified

publishedVersion

Downloaded from Helda, University of Helsinki institutional repository.

This is an electronic reprint of the original article.

This reprint may differ from the original in pagination and typographic detail.

Please cite the original version. 


\title{
Toponyms in Manila and Cavite, Philippines
}

\begin{abstract}
This article examines place names in two Tagalog-speaking Philippine regions, the metropolitan area of Manila and the province of Cavite. The toponyms of the Spanish, American, and independent Philippine periods are compared, based on a sample from historical and contemporary sources including maps, articles, and geographical surveys. The place names include Tagalog endonyms related to local environmental features, religious and anthroponymic commemorative Spanish exonyms, and hybrid forms that combine Tagalog, Spanish, and/or English etymology. More recently, geo-classifiers from English are often found in hybrid forms. The results show that place-naming practices in Metro Manila and Cavite have shifted over time due to the contact between Tagalog, Spanish, and English in the region, and they reflect political and ideological stances.
\end{abstract}

Keywords: Tagalog, Spanish, English, toponyms, Manila, Cavite

\section{Introduction}

This article studies place names in Tagalog regions of the metropolitan area of Manila and the province of Cavite in the Philippines. The Philippines were part of the Spanish empire from the 1500s to the late 1800s when, after the Philippine independence movement and the Spanish-American War, the islands fell under American control in 1898. The United States governed the islands until the country's independence in 1946. These changes in local, colonial, and administrative powers provide a fascinating opportunity to compare place names from a historical perspective. In light of this background, our aim is to discover patterns and principles that govern place-naming practices in this area throughout different historical periods. So far, only a few linguistic studies about place-naming practices in this region have been done (e.g., Medina 1992, Quilis \& Casado-Fresnillo 2008, Tormo Sanz \& Salazar 1968), and this opening

\footnotetext{
Marivic Lesho, University of Bremen, Universitäts-Boulevard 13, 28359 Bremen, Germany. E-mail: lesho@uni-bremen.de

Eeva Sippola, University of Helsinki, PL 24, 00014 Helsinki, Finland.

E-mail: eeva.sippola@helsinki.fi
} 
thus provides new data for the study of the linguistic influences of colonialism in the Philippines.

The patterns and principles of place-naming can reveal interesting generalizations about discursive and ideological practices in different historical periods (Stolz \& Warnke 2016: 31-32). Therefore, in addition to offering an overview of the toponyms and related practices in the Manila and Cavite regions, a second aim of this paper is to investigate whether different historical periods differ or present similarities.

We have chosen to focus our analysis on Metro Manila and the province of Cavite, as these areas were central trading locations in pre-colonial times, and they have remained important administrative, military, and trading centers since the colonial period. For example, Manila was the administrative and religious center of the Spanish and American colonial presence, and the AcapulcoManila galleons docked in the port of Cavite. Furthermore, the Cavite province was the cradle of the Philippine Revolution in the late 19th century, and the American military had a strong presence in the Manila Bay region. Today, Manila and Cavite are the most densely populated areas in the Philippines. The place-naming practices in the region reflect these historical developments and thus provide a wealth of interesting data for our study.

In this article, we use a comparative framework provided in the recent focus on colonial and postcolonial toponomastics (Stolz \& Warnke 2016, in press), which also brings together the different articles in this volume. The toponyms of the precolonial, Spanish, American, and independent Philippine period are compared, based on a sample from historical and contemporary sources including maps, articles, and geographical surveys.

This paper is structured as follows. In Section 2, we provide information on the historical background of the Manila and Cavite regions. In Section 3, some methodological principles and the materials used in the comparative analysis are presented, while the analysis in Section 4 gives an overview of the results and, more specifically, focuses on a number of selected categories that are central to our argument. Section 5 concludes the paper.

\section{Historical background}

Metro Manila is situated on the eastern shore of Manila Bay, in a low-lying area with a number of rivers draining into the sea and connecting the city to other regions. The most notable of these is the Pasig River, which cuts through the city and flows between Manila Bay and Laguna de Bay. The province of Cavite is 
located on the southern shore of the bay. Like Manila, its coastal areas are lowlying plains with a number of rivers flowing into the sea. The southern and western parts of the province, however, are mountainous. The fortified islands at the entrance of Manila Bay, such as Corregidor, are also part of Cavite province, falling under the administration of Cavite City.

When the Spanish first came to Manila and Cavite in 1571, the area was inhabited mainly by Tagalog speakers. However, pre-colonial Manila and the neighboring settlement of Tondo had Muslim rulers tied to the Malay sultanates, particularly in Brunei, and there was also trade with the Chinese (mainly Hokkien speakers) and others throughout the region (Reed 1978). Manila had approximately 2,000 inhabitants during the late precolonial era (Doeppers 1972: 771), but in the region, as throughout the Philippines, most settlements consisted of small clusters of families (a unit known as the barangay) situated along waterways or on the coast (Borromeo 1974: 15, Scott 2004: 5). Cavite was sparsely populated, with the exception of some larger settlements in coastal areas like present-day Bacoor and Kawit (Borromeo 1974:22).

Given the relatively large settlements and active trade already established along the coast of Manila Bay, the region became the center of the Spanish government in the Philippines. Colonial Manila was originally the walled city of Intramuros, which was surrounded by several arrabales 'suburbs', such as Tondo, Binondo, and Dilao, which provided labor, trade, goods, and extra settlement space for the capital (Reed 1978). On the nearby Cavite peninsula, Cavite Puerto was established as a provincial capital because it was the main harbor for the Manila galleon trade. In the rest of Cavite province, indigenous people were resettled into more compact poblaciones 'towns' to facilitate tax collection and evangelization (Doeppers 1972, Borromeo 1974: 29-35, Medina 2001: 4446). The original towns founded during the early colonial period were generally in areas where there were already larger native settlements, such as Kawit and Silang (Medina 2001: 45). During the 1700s, more towns were founded as they split off from friar haciendas or other larger towns, such as Imus and Naic. Nearly half of the Cavite towns, however, were actually founded toward the end of the Spanish colonial period (e.g., Caridad, Ternate, and Amadeo), either as offshoots of neighboring settlements or as buffers to protect rural areas against tulisanismo 'banditry' (Medina 2001: 47-49).

After the Philippine Revolution (1896-1898) and the Spanish-American War (1898), Spain ceded control of the Philippines to the United States. The Americans held official control of the islands until Philippine independence in 1946, 
but they maintained a military presence there for decades afterward, and English became a co-official language of the country (along with Filipino). ${ }^{1}$ This post-Spanish period saw the founding of new towns in Cavite, such as Trece Martires and Tagaytay, and name changes for others, such as General Trias (previously San Francisco de Malabon) and Cavite City (previously the three separate towns of Cavite Puerto, San Roque, and Caridad). Manila also greatly expanded during this time, going from approximately 190,000 people at the end of the Spanish period (Doeppers 1972: 788-789) to 1.78 million in the city proper today, and 12.88 million in the greater metropolitan area (Philippine Statistics Authority 2016). The region of Metro Manila was officially established in 1975, and today it includes sixteen cities and one municipality. It extends as far as Caloocan, Quezon City, and Valenzuela to the north, Marikina and Pasig to the east, and Las Piñas and Muntinlupa to the south.

\section{Methods}

Toponym research in the Philippines can be traced back to the work of missionaries in the Hispanic tradition, who produced grammars and dictionaries with references to local place names and their meanings (Medina 1992: 48). Later, both U.S. and Filipino historians collected toponyms in their research. However, Medina (1992: 50) mentions the lack of toponymic bibliographies and systematic collections of historical maps as challenges for studying place names, in addition to the lack of scientific studies on the naming practices, leading to the use of folk etymologies as explanations. Most data on toponyms have to be collected from individual historical works with a focus on folklore, historical and geographical information, or missionary grammars and descriptions. Despite Medina's (1992, 2001) efforts to study toponyms as a part of documenting local history, the situation has not changed until now.

Tormo Sanz \& Salazar (1968) and Quilis \& Casado-Fresnillo (2008) describe Hispanic names in the Philippines and shed light on the early motivations and practices on colonial place-naming in the region, which started with the islands and coastal regions, and with time, moved towards the interior. As a consequence, regions with a heavier colonial presence and higher population density

\footnotetext{
1 Filipino (formerly called Pilipino) is a standardized register originally based on Tagalog. According to the 1987 constitution, Filipino and English are co-official languages, and Spanish (along with Arabic) is a voluntary language, meaning that it is no longer required in the education system or other official contexts (Gonzalez 1998).
} 
have a higher number of Spanish names, while isolated areas have more autochthonous names (Quilis \& Casado-Fresnillo 2008: 538, 540). At the level of the archipelago, the large islands have autochthonous names, with the exception of Negros (Quilis \& Casado-Fresnillo 2008: 536). As Tormo Sanz \& Salazar (1968: 2098-2102) noted, the Spanish tended to maintain indigenous toponyms at the beginning of the colonial period, even though they had difficulty with the phonology of Philippine languages, as reflected in spelling inconsistencies in chronicles written by early explorers (e.g., Manila appears as Maniolas, Mainillas, and Manilas in various sources). After the initial phase of the colonial period, however, more Spanish names were used, sometimes blended with Tagalog forms (Tormo Sanz \& Salazar 1968: 2102-2106).

Quilis \& Casado-Fresnillo (2008) cover names relating to political geography (provinces, settlements, street names, etc.) based on the Roadmap of the Philippines (1995) and give percentages about the number of Hispanic names, but they do not specify the exact number of toponyms analyzed. Street names have the highest number of Hispanic names, (46.8\%) and the numbers decrease when moving towards larger units, such as settlements $(28.3 \%)$ and provinces (18.4\%) (Quilis \& Casado-Fresnillo 2008: 538). They report that in Cavite, $56 \%(n=25)$ of the town names are of Spanish origin (Quilis \& CasadoFresnillo 2008: 541). In general, systematic linguistic studies from a crosslinguistic perspective on place-naming practices in Cavite province or Manila do not yet exist. Our study aims to partly fill this lacuna of research.

The material for this paper consists of a sample from historical and contemporary sources, including maps and geographical surveys. The availability of historical sources with information on Philippine geography is relatively good. In recent decades, the Spanish National Library has made an effort to digitalize colonial and other historical publications and documents, including maps, which can be accessed through the library's digital collections. Similarly, the University of Alcalá hosts the Spanish Ancient Cartography e-Library, which provides a wealth of sources for those interested in exploring maps from the Spanish colonial period.

The earliest source in our sample is a Spanish map from 1734, and the latest maps were produced by the National Mapping and Resource Information Authority of the Philippines (NAMRIA) in the 1990s and early 2000s. In addition, place names were collected from geographical surveys, such as the Diccionario geográfico-estadístico-histórico de las islas Filipinas (Buzeta \& Bravo 1850) and Historia geográfica, geológica y estadística de Filipinas (Cavada y Mendez de Vigo 1876). Table 1 gives an overview of the maps used in the sample. 
Table 1: Maps of the Cavite province and Manila in the sample.

\begin{tabular}{|c|c|c|c|c|}
\hline Title & $\begin{array}{l}\text { Publication } \\
\text { year }\end{array}$ & $\begin{array}{l}\text { Total number } \\
\text { of examples }\end{array}$ & Area of focus & $\begin{array}{l}\text { Authors (publish- } \\
\text { ing authority) }\end{array}$ \\
\hline $\begin{array}{l}\text { Carta hydrographica y } \\
\text { chorographica de las } \\
\text { Yslas Filipinas }\end{array}$ & 1734 & 26 & Manila and Cavite & $\begin{array}{l}\text { Murillo \& Bagay } \\
\text { (Spanish) }\end{array}$ \\
\hline $\begin{array}{l}\text { Plano de la ciudad y } \\
\text { plaza de Manila }\end{array}$ & 1766 & 36 & Manila & $\begin{array}{l}\text { Zermeño } \\
\text { (Spanish) }\end{array}$ \\
\hline $\begin{array}{l}\text { Plano del puerto de } \\
\text { Cavite con sus ense- } \\
\text { nadas de Cañacao y } \\
\text { Bacoor y parte de la } \\
\text { bahía de Manila hasta } \\
\text { Parañaque }\end{array}$ & 1874 & 20 & $\begin{array}{l}\text { Cavite and Manila } \\
\text { Bay }\end{array}$ & $\begin{array}{l}\text { Riudavets \& } \\
\text { Villavicencio } \\
\text { (Spanish) }\end{array}$ \\
\hline $\begin{array}{l}\text { Carta General del } \\
\text { Archipiélago Filipino... }\end{array}$ & 1875 & 10 & Manila and Cavite & $\begin{array}{l}\text { Montero y Gay et } \\
\text { al. (Spanish) }\end{array}$ \\
\hline $\begin{array}{l}\text { A Chart of the Great } \\
\text { Bay of Manilla and } \\
\text { Harbour of Cavita }\end{array}$ & 1789 & 30 & Manila and Cavite & $\begin{array}{l}\text { Nicholson \& } \\
\text { Gilbert (British) }\end{array}$ \\
\hline $\begin{array}{l}\text { Plano de la Ciudad de } \\
\text { Manila Capital de las } \\
\text { Yslas Filipinas } \\
\text { Siendo... }\end{array}$ & 1819 & 38 & Manila & Herrera (Spanish) \\
\hline $\begin{array}{l}\text { Carta Esférica del } \\
\text { Estrecho de Sn. } \\
\text { Bernardino, é islas } \\
\text { adyacentes }\end{array}$ & 1856 & 9 & Manila Bay & $\begin{array}{l}\text { Bernacci, Espejo, } \\
\text { Gangoiti, } \\
\text { Noguera, Roca de } \\
\text { Torre (Spanish) }\end{array}$ \\
\hline $\begin{array}{l}\text { City of Manila. Philip- } \\
\text { pine Islands }\end{array}$ & 1920 & 53 & Manila & Bach (American) \\
\hline $\begin{array}{l}\text { Manila, Philippines } \\
7172 \text { II }\end{array}$ & 1995 & 16 & $\begin{array}{l}\text { Central Metro } \\
\text { Manila }\end{array}$ & NAMRIA (Filipino) \\
\hline $\begin{array}{l}\text { Region IV, Cavite, } \\
\text { Mendez, sheet } 3129\end{array}$ & $1993 / 2005$ & 32 & Southern Cavite & NAMRIA (Filipino) \\
\hline $\begin{array}{l}\text { Region IV, Cavite, } \\
\text { Cavite City, sheet } 3129\end{array}$ & $2001 a / 2005$ & 35 & Northern Cavite & NAMRIA (Filipino) \\
\hline $\begin{array}{l}\text { Maragondon, Philip- } \\
\text { pines, sheet } 7171 \text { IV }\end{array}$ & $2001 b / 2005$ & 52 & $\begin{array}{l}\text { Maragondon and } \\
\text { Manila Bay islands }\end{array}$ & NAMRIA (Filipino) \\
\hline $\begin{array}{l}\text { National Capital Regi- } \\
\text { on, Metro Manila, } \\
\text { Muntinlupa City, sheet } \\
\text { 3229-IV }\end{array}$ & $2001 c / 2002$ & 3 & $\begin{array}{l}\text { Southern Metro } \\
\text { Manila }\end{array}$ & NAMRIA (Filipino) \\
\hline
\end{tabular}


Table 1: (continued)

\begin{tabular}{lllll}
\hline $\begin{array}{l}\text { National Capital Re- } \\
\text { gion, Quezon City, } \\
\text { sheet 3230-III }\end{array}$ & 2001d & 30 & $\begin{array}{l}\text { Northern/Eastern } \\
\text { Metro Manila }\end{array}$ & NAMRIA (Filipino) \\
\hline
\end{tabular}

The principles governing the data collection were the focus on the two regions and the availability of material in digital form. After localizing the main sources, these were examined and processed, and the place names were manually coded into an index. All the geographical names in the maps forming our sample were collected and indexed following the categories in Stolz \& Warnke (this volume). This source type yielded over 350 place names and other indications, such as names of forts and gates, from the maps. Due to the fact that the authors of these maps were cartographers working for the colonial or national authorities and for marine purposes, salient categories of geo-objects in these maps included oikonyms (settlement names, i.e. districts, cities, towns, etc.) as well as islands, from the category of choronyms (referring to larger geographical units). Many names are repeated in different sources, sometimes with slight modifications of the orthography, or creating hybrid forms mixing elements from several languages (see 4.3).

Other source types were selected to complement the core materials. As these included several place names also from other parts of the Philippines, we narrowed down the data collection to the above-mentioned categories of settlement names and islands for more detailed analysis in section four.

\section{Analysis}

Settlement names in our corpus show a relatively even distribution of patterns. A little less than one-third of the settlement names are Tagalog endonyms, onethird are Spanish exonyms, and the remainder are hybrid forms. Although there was a large Chinese and Chinese-Filipino mestizo presence in colonial Manila and Cavite (Gealogo 2005, 2011), Hokkien had almost no influence on how places were named.

Many endonyms describe natural features of the area, and probably arose during history without a clear date of naming, but these were often adapted by the Spanish colonial administrators. With regard to the Spanish exonyms, it is clear that the denominators were colonial agents, and the number of names that have prevailed until today shows that the local population adapted these nam- 
ing practices to a large extent. The English/American exonyms are of a different character, mainly adding geo-classifiers to already existing names. The hybrid settlement names show three patterns: Tagalog-Spanish, e.g. San Pedro Macati, where the first part of the name comes from a Spanish saint and the latter is a Tagalog adjective referring to a low tide or ebb; Tagalog-English, e.g. the later name of Makati City, referring to the same area; and even Spanish-English naming patterns, such as Quezon City, which combines a Spanish family name with the English denominator city.

Compared to the settlement names, the number of exonyms in the category of islands is higher: about two-thirds of the island names are Spanish exonyms, such as Caballo 'horse', Corregidor 'magistrate', El Fraile 'the friar', and La Monja 'the nun'. However, these names can be combined in hybrid forms with Tagalog pulo 'island', as in Pulo Caballo, or with English descriptives, as in Caballo Island or Corregidor Island.

Regarding the number and type of structural features, we must treat endonyms and exonyms separately, due to the typological nature of the languages in question. Tagalog is an Austronesian, Philippine language with slight morphological inflection and affixation. In Tagalog endonyms, both one-unit and multi-morpheme names occur, both being descriptive of the characteristics of the place. In the multi-unit names, the use of the adjectival prefix ma-, indicating an abundance of something, is quite common. For example, Maragondon (< Tag. madagundong 'full of noise') refers to the substantial noise produced by the local river as it flows through the rocks. In contemporary official names, possessive constructions with the linker $n g$ are common, as in Lungsod $n g$ Malabon 'City of Malabon'.

In exonyms, several patterns occur as well. As a Romance language, Spanish makes use of articles and modifiers in the noun phrase that can be both preand postposed. Multi-unit structures include combinations of articles and nouns, such as Las Piñas 'the pineapples' or La Estanzuela 'the estate'; possessive de-constructions, such as Barrio de Dilao (<Sp. barrio de 'neighborhood of', Tag. dilaw 'yellow') or San Juan del Monte 'St. John of the Mountain'; or complex names, such as General Trias (a military title and last name) or Trece Martires City ('Thirteen Martyrs City'). In religious names, such as Santa Cruz, San Juan, or San Roque, the binary structure typical of colonial place names (Stolz \& Warnke 2015, 2016: 37) is evident. Adjectival constructions, such as Cavite Viejo 'old Cavite', also occur. In hybrid forms with Spanish, the matrix is the Spanish phrase, where Tagalog (or other) elements are included. In the hybrid forms with English elements, English descriptors or geo-classifiers are generally postposed to the Tagalog or Spanish part of the name, as in Caballo 
Island or Cavite City, although possessive of-constructions also occur, e.g. City of Caloocan or City of Taguig.

\subsection{Tagalog endonyms}

Place names in Tagalog and other Philippine languages often refer to plants or other natural objects that are common in the area (Medina 1992: 56). For example, the name Manila or Maynila refers to the presence of either mangrove shrubs or indigo plants (< Tag. may nila $(d)$ 'there are nila plants'). Quiapo, a district of Manila, is a hispanicized spelling of kiyapo 'tropical duckweed'. According to Medina (2001: 52), the Cavite town of Masilao (now Amadeo) was named after the bright red flowers of the dapdap 'coral tree' (from Tag. silaw 'glare', masilaw 'dazzling').

Another common Tagalog pattern is to name places after salient geographic features. Examples of this pattern include the towns of Silang 'mountain pass', Imus 'cape, headland', Bacoor 'highland, plateau', and Tagaytay 'ridge'. The word malabon 'having many silt deposits' was also used in the names of two towns in Cavite: Santa Cruz de Malabon (now Tanza) and San Francisco de Malabon (now General Trias). Malabon is also the name of one of the cities in Metro Manila; it is located at the mouth of the Tullahan River, where there would have been many silt deposits, although there is a common folk etymology that the name comes from malabong 'having many bamboo shoots'.

\subsection{Spanish exonyms}

According to Tormo Sanz \& Salazar (1968) and Quesada \& Casado-Fresnillo (2008: 534-544), colonial Spanish names for Filipino provinces, towns, and districts tend to refer to religion, places in Spain or elsewhere, important historical or political figures, or given names. Given names are also often religious in nature, as in Latin America (Val Julián 2011: 74-78). Most of these types occur in Manila and Cavite as well. Examples of places with religious names include the Ermita 'hermitage' and Santa Cruz 'holy cross' districts of Manila and the towns of San Roque and Rosario 'rosary' in Cavite. During the late colonial era, some newly established Cavite towns were named in honor of Spanish political figures, such as Dasmariñas (referring to Gómez Pérez Dasmariñas, the seventh governor-general of the Philippines), Amadeo (King Amadeo I, who reigned from 1870 to 1873), and Alfonso (King Alfonso XII, who reigned from 1874 to 1885). In the case of Amadeo and Alfonso, older Tagalog settlement names were 
replaced (Masilao 'dazzling' and Alas-as 'pandan, screwpine', respectively). Another town founded during the 19th century, Carmona, shares its name with a town in southern Spain. In addition to the patterns observed by Quesada \& Casado-Fresnillo (2008), there were occasionally colonial Spanish names that described the function or environment of the town, as in the case of Salinas 'salt flats, saltworks' (now Rosario) and Tierra Alta 'high ground' (now Noveleta).

After the end of the Spanish era, some towns were given names that are of Spanish origin but honor Filipino national heroes. For example, in 1914, San Francisco de Malabon was renamed General Trias, after local hero Mariano Trías, who was an active figure in the Philippine Revolution and in the postSpanish government. Similarly, Trece Martires 'Thirteen Martyrs', founded in 1954, was named in honor of a group of men who were executed in 1896 for conspiring against the Spanish in Cavite Puerto. Another Cavite town seems to still be in the process of negotiating its postcolonial name. Bailén, which shares a name with another town in southern Spain, was changed to General Emilio Aguinaldo in honor of the first Philippine president after his death in 1964. However, the town's name was changed back to Bailén in 2012, although it is not yet fully official.

\subsection{Hybrid place names}

Names like San Francisco de Malabon (now General Trias) and San Pedro Macati (now Makati) reflect the mixing of Spanish and Tagalog forms that occurred during the colonial era. In these two examples, the toponyms combine Catholic saint names with descriptive Tagalog names. Another type of hispanicized form involves the changing of Tagalog names to conform to Spanish phonology. For example, according to Medina (1992: 56), the Manila district of Malate "should rightly have been called Maalat" (< Tag. maalat [maPalat] 'salty'), but the Spanish would have had difficulty pronouncing the intervocalic glottal stop and the syllable-final /t/.

American influence on hybrid toponyms in the region is mainly found in the form of geo-classifiers such as city, municipality, island, and river (e.g., City of Makati or Makati City, Municipality of Noveleta, Corregidor Island, and Pasig River). However, these official terms also co-exist with their equivalents in Filipino, such as lungsod 'city', bayan 'municipality', isla 'island' (< Sp. isla), and ilog 'river' (e.g., Lungsod ng Makati, Bayan ng Noveleta, Isla ng Corregidor, and Ilog Pasig). The use of these geo-classifiers has led to hybrid forms with both Spanish and Tagalog, as in Caballo Island (<Sp. caballo 'horse') and Municipality of Silang (< Tag. silang 'mountain pass'). 
The sample includes only one example of a toponym related to Hokkien. One tip of the Cavite City peninsula is known today as Sangley Point, a hybrid Hokkien-English name, which is a translation of the earlier Spanish-Hokkien form Punta (de) Sangley. During the Spanish era, sangley referred to Chinese people, particularly traders, living in the Philippines. The origins of this term are not entirely clear, but it appears to derive from Hokkien siang ${ }^{5}$ lai ${ }^{5}$ 'constantly coming' or sing' ${ }^{1} l i^{2}$ 'trade' (Klöter 2011: 9).

\subsection{English exonyms}

At the broad geographical level, American influence on toponyms in the region has not been very strong. As mentioned above, it is mainly found in the form of geo-classifiers in hybrid forms. In addition to these, the American militarization of Manila and Cavite City has had some slight influence on toponyms in the region. For example, the islands of Corregidor, Caballo, Carabao, and El Fraile were also designated as Fort Mills, Fort Frank, Fort Hughes, and Fort Drum, respectively. Aside from these fort names and the geo-classifiers, however, English toponyms are more commonly found at levels below town or district (e.g., barangay 'neighborhood' names like Greenhills in San Juan and Fairview in Quezon City, or business names). Spanish and Tagalog place names are still far more frequent.

\subsection{Name changes}

Several of the examples presented above show that renaming and combining elements from new languages with existing names has been quite common in the Manila and Cavite regions. The practical and symbolic value of placenaming practices is shown in these changes (see also Stolz \& Warnke 2016: 3335). In addition, it is not surprising that naming practices reflect other linguistic practices in the multilingual environment, where people use several languages in their daily communication, and borrowing and code-switching are frequent.

The multiple names of the municipality of Ternate, which is located at the mouth of the Maragondon River at the entrance to Manila Bay, is a case in point. During the Spanish era, Ternate was known by the descriptive name Barra de Maragondon 'sandbar/river mouth of Maragondon'. It was an outlying barrio 'neighborhood' of the town of Maragondon and an enclave where people spoke a variety of Chabacano, a Philippine-Spanish creole. The barrio was established as a separate town in the mid-1800s. It was renamed Ternate during the early 
1900 s as a reference to the ancestors of the Chabacano-speaking population, who descended from a group of soldiers who were relocated from the Moluccan island of Ternate to the Manila Bay region during the late 1600s. Today, the municipality is officially called Bayan ng Ternate in Filipino, but the local government also uses both Municipalidad de Barra and Municipality of Ternate on their website (http://www.ternate.cavite.gov.ph). The inhabitants of the town call it Ternate in Filipino/Tagalog and English, Bahra or Barra (from Barra de Maragondon) in Chabacano, and also often refer to a third name, Wawa (< Tag. 'river mouth, delta'), which was used earlier by the local Tagalog-speaking population.

Another example of the shifting of names is related to the towns now known as Cavite City and Kawit. The Tagalog word kawit means 'hook', and the place name refers to the shape of the peninsula where Cavite City is located. This peninsula was also known simply as Tangway (< Tag. 'peninsula') in the precolonial era (Borromeo 1974: 29). The Spanish changed the name of the mainland settlement of Kawit to Cavite, which conforms better to Spanish phonology, and then began referring to it as Cavite Viejo 'old Cavite' after they established the town of Cavite Puerto (or Puerto de Cavite 'port of Cavite') on the peninsula.

The names then changed again after the Spanish era. Cavite Viejo opted to revert to its original Tagalog name, Kawit, in 1907. Not coincidentally, the town also sees itself as the birthplace of Philippine independence. Cavite City residents are equally proud of the important roles their ancestors played in the revolution. However, after Cavite Puerto, San Roque, and Caridad were united in 1903, the name Cavite was retained because the peninsula was the most hispanicized area of the province, and another variety of Chabacano was widely spoken in all three former towns.

\section{Concluding remarks}

In summary, the patterns and principles that govern place-naming practices in Manila and Cavite show both maintenance of local names and renaming according to colonial customs in rather equal measure. Structurally speaking, both single- and multi-unit names occur in all languages present.

Place-naming practices in Metro Manila and Cavite have shifted over time due to the contact between Tagalog, Spanish, and English in the region. Filipinos originally tended to name places based on natural characteristics of the local environment, but the Spanish introduced the practices of giving settle- 
ments religious names or honoring important people. After the Spanish period, Filipinos retained many of these names and practices; however, emphasizing their freedom from Spain, they also chose to revert to older Tagalog names in some cases or to honor Filipino heroes in others. English influence, in contrast, is mostly seen in how military zones and administrative units like forts, municipalities, and cities are labeled, reflecting its status as the dominant language of the Philippine government and the main purpose of the American colonization there. Hokkien was historically also present in the region, but there is almost no trace of it in the place names.

These shifts in naming practices correspond to the different stages of the development of the Philippines from precolonial times to present, as identity in Manila and Cavite has gradually shifted from local to national in response to ideological changes introduced by two colonial forces and eventual independence. As the examples in this paper have shown, this process is not complete. Settlement names in the Philippines are continuing to undergo slight changes, for example by reverting to older names or using Filipino settlement labels alongside English ones, as place identity continues to develop during the postcolonial era.

Acknowledgments: We would like to thank Thomas Stolz and Ingo Warnke for their encouragement and comments in writing this paper. We are also grateful to Aziza Nawazir and Christoph Wolf for helping us to collect and organize the data. 


\section{References}

Bach, John. 1920. City of Manila, Philippine Islands. Manila: Bureau of Commerce and Industry. http://www.loc.gov/resource/g8064m.ct003077 (11 November 2015).

Bernacci, Juan, J. Espejo, Juan de Gangoiti, Juan Noguera \& Federico Roca de Torres. 1856. Carta Esférica del Estrecho de Sn. Bernardino, é islas adyacentes que comprehende desde la entrada del Pto. de Palapa en la Isla de Samar hasta la Bahia de Manila, y desde la Latitud de nำ $18^{\prime}$ hasta $14^{\circ} 26^{\prime} \mathrm{N}$ H. 194 construida en la Direccion de Hidrografia segun las Operaciones practicadas en 1792 y 1793 por los Oficiales y Pilotos de las Corvetas del Rey Descubierta y Atrevida, por las que ejecutó en 1804 el Capitan de Fragata de la Real Armada D. Juan Bernacci, con las nuevamente hechas en los años 1840 al 1843 ... presentada á S. M. por el Exmo. Sr. D. Mariano Roca de Togores, Marqués de Molins y Ministro de Marina ; J. Espejo la delineó ; Jn. Noguera la grabó ; Juan de Gangoiti la letra. Madrid: Dirección de Hidrografía. http://bdh.bne.es/bnesearch/detalle/bdh0000070265 (1 June 2016).

Borromeo, Soledad Masangkay. 1974. El Cadiz filipino: Colonial Cavite, 1571-1896. Berkeley: University of California, Berkeley dissertation.

Buzeta, Manuel \& Felipe Bravo. 1850. Diccionario geográfico, estadístico, histórico de las islas Filipinas. Madrid: José C. de la Peña.

Cavada y Mendez de Vigo, Agustin de la. 1876. Historia geográfica, geológica y estadística de Filipinas. Manila: Imp. de Ramirez y Giraudier.

Doeppers, Daniel F. 1972. The development of Philippine cities before 1900. The Journal of Asian Studies 31(4). 769-792.

Gealogo, Francis A. 2005. Population history of Cavite during the nineteenth century. The Journal of History 51(1). 308-339.

Gealogo, Francis A. 2011. Counting people: Nineteenth-century population history of four Manila arrabales using the Planes de Almas. Philippine Studies 59(3). 399-423.

Gonzalez, Andrew. 1998. The language planning situation in the Philippines. Journal of Multilingual and Multicultural Development 19(5). 487-525.

Herrera, Francisco Xavier de. 1819. Plano de la Ciudad de Manila Capital de las Yslas Filipinas Siendo su Situación Geográfica en la Latitud Septentrional de 14ํy y $36^{\prime}$ y la Longitud Oriental de $127^{\circ}$ y $15^{\prime}$ respecto a Cadiz y su diferencia de Meridiano contada por el Oeste de 15 horas y 31' minutos la Circunferencia 4166 Varas... Por el Deposito Topografico de Manila Año de 1819. Manila: Depósito Topográfico. http://bdh.bne.es/bnesearch/detalle/bdh0000023418 (1 June 2016).

Klöter, Henning. 2011. The language of the Sangleys: A Chinese vernacular in missionary sources of the seventeenth century. Leiden: Brill.

Medina, Isagani R. 1992. Problems concerning place name research in the Philippines. The Journal of History 36/37(1/2). 47-57.

Medina, Isagani R. 2001. Growth of towns and parishes in Cavite, 1571-1880. In Isagani R. Medina \& Mirana R. Medina (eds.), Ang Kabite sa gunita: Essays on Cavite and the Philippine Revolution, 43-55. Quezon City: University of the Philippines Press.

Montero y Gay, Claudio, Juan Noguera, E. Fungairiño, Juan de Gangoiti \& P. Serra. 1875. Carta General del Archipiélago Filipino (en dos hojas) H. 5960 Levantada Principalmente por la Comisión Hidrográfica al mando del Capitan de navío D. Claudio Montero y Gay hasta el año 1870 con adiciones hasta 1875; J. Noguera la construyó ; P. Serra go el contorno, 
E. Fungairiño la topografía ; J. de Gangoiti go la letra. Madrid: Dirección de Hidrografía. http://bdh.bne.es/bnesearch/detalle/bdh0000016066 (1 June 2016).

Murillo, Pedro Velarde \& Nicolás de la Cruz Bagay. 1734. Carta hydrographica y chorographica de las Yslas Filipinas. Manila: n.p. http://www.loc.gov/resource/g8060.ct003137

(23 November 2015).

National Mapping and Resource Information Authority (NAMRIA). 1993 (reprinted 2005). Region IV, Cavite, Mendez, sheet 3129. Makati: Department of Environment and Natural Resources. www.namria.gov.ph/3129-IIMendez.html (1 December 2015).

National Mapping and Resource Information Authority (NAMRIA). 1995. Manila, Philippines, sheet 7172 II. Makati: Department of Environment and Natural Resources. http://www.namria.gov.ph/7172-IIManila.html (1 December 2015).

National Mapping and Resource Information Authority (NAMRIA). 2001a (reprinted 2005). Region IV, Cavite, sheet 3129. Makati: Department of Environment and Natural Resources. http://www.namria.gov.ph/3129-ICaviteCity.html (1 December 2015).

National Mapping and Resource Information Authority (NAMRIA). 2001b (reprinted 2005). Maragondon, Philippines, sheet 7171 IV. Makati: Department of Environment and Natural Resources. http://www.namria.gov.ph/7171-IVMaragondon.html (1 December 2015).

National Mapping and Resource Information Authority (NAMRIA). 2001c (reprinted 2002). National Capital Region, Muntinlupa City, sheet 3229-IV. Makati: Department of Environment and Natural Resources. http://www.namria.gov.ph/3229-IVMuntinlupaCity.html (2 June 2017).

National Mapping and Resource Information Authority (NAMRIA). 2001d. National Capital Region, Quezon City, sheet 3230-III. Makati: Department of Environment and Natural Resources. http://www.namria.gov.ph/3230-IIIQuezonCity.html (2 June 2017).

Nicholson, William \& William Gilbert. 1789. A Chart of the Great Bay of Manilla and Harbour of Cavita: describing all the Islands, Rivers, Bays, Rocks, Sands \& Dangerous Shoals ... Surveyed and Drawn whit great Accuracy by Wm. Nichelson Master of his Majesty's Ship Elizabeth at the taking of Manilla. London: Published according to Act of Parliament by Willm. Gilbert. http://bdh.bne.es/bnesearch/detalle/bdh0000130734 (1 June 2016).

Philippine Statistics Authority. 2016. Population of the National Capital Region (based on the 2015 Census of Population). https://psa.gov.ph/content/population-national-capitalregion-based-2015-census-population-0 (26 May 2017).

Quilis, Antonio \& Celia Casado-Fresnillo. 2008. La lengua española en Filipinas: historia, situación actual, el chabacano, antología de textos. Madrid: Consejo Superior de Investigaciones Científicas.

Reed, Robert R. 1978. Colonial Manila: The context of Hispanic urbanism and process of morphogenesis. Berkeley and Los Angeles: University of California Press.

Riudavets, José \& Manuel Villavicencio. 1874. Plano del puerto de Cavite con sus ensenadas de Cañacao y Bacoor y parte de la bahía de Manila hasta Parañaque H. 655 levantado en 1872 por la Comisión Hidrográfica de Filipinas al mando del teniente de navío de 1aㅡ clase D. Manuel Villavicencio ; J. Riudavets lo grabó. Madrid: Dirección de Hidrografía. http://bdh.bne.es/bnesearch/detalle/bdh0000054540 (1 June 2016).

Roadmap of the Philippines. 1995. Manila: The National Book Store.

Scott, William Henry. 2004. Barangay: Sixteenth century Philippine culture and society. Quezon City: Ateneo de Manila University Press.

Stolz, Thomas \& Ingo H. Warnke. 2015. Aspekte der kolonialen und postkolonialen Toponymie unter besonderer Berücksichtigung des deutschen Kolonialismus. In Daniel Schmidt- 
Brücken, Susanne Schuster, Thomas Stolz, Ingo H. Warnke \& Marina Wienberg (eds.), Koloniallinguistik. Sprache in kolonialen Kontexten, 107-176. Berlin: De Gruyter.

Stolz, Thomas \& Ingo H. Warnke. 2016. When places change their names and when they do not. Selected aspects of colonial and postcolonial toponymy in former French and Spanish colonies in West Africa - the cases of Saint Louis (Senegal) and the Western Sahara. International Journal of the Sociology of Language 239. 29-56.

Stolz, Thomas \& Ingo H. Warnke. in press. Comparative colonial toponomastics. Evidence from German and Dutch colonial placenames. In Rita Heuser \& Mirjam Schmuck (eds.), Stiefkinder der Onomastik. Berlin: De Gruyter.

Stolz, Thomas \& Ingo H. Warnke. this volume. System- und diskurslinguistische Einblicke in die vergleichende Kolonialtoponomastik. Eine gemeinsame Einführung.

Tormo Sanz, Leandro \& Milagros Salazar. 1968. Datos sobre la toponimia en Filipinas. In Antonio Quilis, Ramón B. Carril \& Margarita Cantarero (eds.), XI Congreso International de Lingüística y Filología Románicas: Actas, vol 4, 2097-2108. Madrid: CSIC.

Val Julián, Carmen. 2011. La realidad y el deseo. Toponymie du découvreur en Amérique espagnol. In Julien Roger, Marie-Linda Ortega \& Marina Mestre-Zaragoza (eds.), La realidad y el deseo. Toponymie du découvreur en Amérique espagnol. Carmen Val Julián, 25-144. Lyon: ENS Éditions.

Zermeño, Juan Martín. 1766. Plano de la ciudad y plaza de Manila, capital de la isla de Luzón, con el proyecto para la mejor defensa que propuso a S.M. el Teniente General don Juan Martin Zermeño.

http://bdh.bne.es/bnesearch/detalle/bdh0000018613 (1 June 2016). 